\title{
HUBUNGAN ANTARA JENIS POLA ASUH ORANG TUA TERHADAP RESIKO PERILAKU BULLYING SISWA-SISWI SMP PASUNDAN 2 KOTA BANDUNG
}

\author{
Asri Handayani ${ }^{1}$, Clara Yollanda. $\mathrm{R}^{2}$, Moch. Hasan Wirayuda ${ }^{3}$, Yaniar Dewi. $\mathrm{N}^{4}$ \\ asri.handayani82@gmail.com \\ 1,2,3,4 Program Studi Sarjana Keperawatan STIKes Dharma Husada Bandung
}

\begin{abstract}
ABSTRAK
Perilaku bullying sering dianggap hal biasa oleh siswa-siswi SMP pada saat ini, alasan dari bullying tersebut hanyalah untuk kesenangan, karena dirumah atau di lingkungan rumah mereka tidak bisa berperilaku seperti itu karena takut di marahi orangtuanya sehingga tidak bebas dalam bermain dengan teman sebayanya. Penelitian ini bertujuan untuk melihat hubungan antara jenis pola asuh orang tua terhadap risiko perilaku bullying siswa-siswi SMP Pasundan 2 Kota Bandung. Metode penelitian yang digunakan adalah metode kuantitatif dengan pendekatan cross sectional study, teknik pengambilan sampel ini adalah proportional stratified random sampling. Jumlah sampel yang digunakan adalah 70. Data diolah dengan analisis univariat dan bivariat dengan uji chi-square menggunakan program pengolahan data. Hasil penelitian menunjukkan $37,1 \%$ orang tua menerapkan jenis pola asuh permisif, resiko perilaku bullying tinggi sebanyak 52,9\% dan resiko perilaku bullying rendah $47,1 \%$, hasil uji statistik yang peneliti lakukan didapat, nilai $p$-value > 0,05 yaitu 0,068 dengan $r=7,118$, menunjukan tidak ada hubungan yang signifikan antara variabel jenis pola asuh orang tua terhadap variabel resiko perilaku bullying. Untuk itu orang tua diharapkan dapat bekerjasama dengan pihak sekolah dalam mengawasi perilaku siswa-siswi untuk menghentikan perilaku bullying yang selama ini sering dilakukan oleh siswa-siswi, dan perawat diharapkan membuat upaya-upaya untuk mencegah dan mengurangi bullying dengan penerapkan asuhan keperawatan bagi para pelaku atau korban bullying .
\end{abstract}

Kata kunci : Pola Asuh Orang Tua, Resiko Perilaku Bullying

\section{PENDAHULUAN}

Angka kejadian bullying dalam 9 tahun terakhir mengalami peningkatan pesat dimana, pada tahun 2008 angka kejadian bullying di SMP sebesar $66.1 \%$ dan menunjukkan bahwa $10-60 \%$ siswa di indonesia mengatakan mengalami kekerasan baik fisik ataupun verbal. Ada beberapa faktor yang menyebabkan teradinya bullying pada remaja salah satunya adalah pola asuh keluarga atau orangtua. Pola asuh orang tua sendiri memiliki beberapa macam gaya atau sikap. Seperti yang dikemukakan oleh Gordon (dalam Syamaun, 2012: 28) bahwa pola pengasuhan terbagi menjadi tiga yaitu pola otoriter, demokratis dan permisif.

\section{TINJAUAN PUSTAKA}

Masa remaja menurut Hall (dalam Sarwono, 2011), merupakan masa strum and drang (topan dan badai), masa penuh 
dengan emosi dan adakalanya emosi tersebut tidak terkontrol, yang terjadi karena adanya pertentangan nilai-nilai dan perbedaan presepsi atau pola pikir pada remaja. Dalam perkembangannya remaja cenderung memiliki hasrat untuk mencoba hal-hal baru, baik itu hal positif maupun negatif, hal negatif yang dicoba salah satunya adalah kenakalan remaja. Kenakalan remaja merupakan kumpulan dari berbagai perilaku remaja yang tidak dapat diterima secara sosial hingga terjadi tindakan kriminal. Salah kenakalan remaja yang sering di jumpai adalah Bullying.

Menurut Coloroso (2006) pelaku bullying akan terperangkap dalam peran sebagai pelaku bullying, mereka tidak dapat membina hubungan yang sehat, tidak dapat memandang sesuatu dari pandangan lain , tidak memiliki rasa empati, menganggap bahwa dirinya kuat, dan merasa banyak yang menyukainya, hal tersebut dapat mempengaruhi pola hubungan sosialnya di masa yang akan datang. Faktor-faktor yang menyebabkan terjadinya bullying, menurut Ariesto (2009) adalah keluarga, sekolah, dan kelompok sebaya.

Keluarga merupakan sekolah pertama anak, dimana anak mulai mempelajari semuanya dari mulai keluarga yang ada di rumah dan pada akhirnya akan menjadi nilai dan perilaku yang dia anut (hasil imitasi). Pola asuh orang tua sendiri memiliki beberapa macam gaya atau sikap. Seperti yang dikemukakan oleh Gordon (dalam Syamaun, 2012: 28) bahwa pola pengasuhan terbagi menjadi tiga yaitu pola otoriter, demokratis dan permisif.

\section{METODE PENELITIAN}

Penelitian ini menggunakan metode deskriptif, dengan pendekatan cross sectional, populasi dalam penelitian ini adalah siswa-siswi kelas VIII dan IX SMP Pasundan 2 Kota Bandung, jumlah sempel pada penelitian ini berumlah 70 orang sampel, dengan menggunakan tekhnik, proportional stratified random sampling, yaitu pengambilan sempel berstrata dimana populasi di kelompokkan dalam strata tertentu kemudian diambil sample secara random.

Penelitian ini menggunakan dua kuisioner, kuesioner pertama yang digunakan adalah parental authority questionnaire (PAQ) yang dibuat oleh Buri (1991) dan dikembangkan oleh Dwairy dkk (2006), yang diterjemahkan kedalam bahasa Indonesia dan sudah di uji validitas kuisioner ini berisi 30 pertanyaan tentang jenis pola asuh orang tua, dimana masingmasing kategori jenis pola asuh memiliki 10 pertanyaan yang di sebar. Kuisioner kedua merupakan kuisioner untuk resiko perilaku bullying menggunakan kuisioner tertutup, yang dibuat oleh Atfiyanah (2013) yang telah di uji validasi kuisioner 
ini menggunakan skala model likert yang memiliki empat alternatif jawaban yaitu : SS (sangat sesuai), S (sesuai), TS (tidak sesuai), STS (sangat tidak sesuai), yang terdiri dari 28 pernyataan. Kedua kuesioner merupakan kuesioner baku dan sudah teruji validitas

Peneliti menyebarkan kuisioner tersebut kepada para responden, setelah responden mengisi kuisioner maka peneliti melakukan pengecekan kelengkapan isi kuisioner, dan yang selanjutnya akan mulai diproses pengolahan data. Data tersebut kemudian di analisis menggunakan analisis univariat yang digunakan untuk menggambarkan masing-masing variabel dan analisis bivariat, yang digunakan untuk mengetahui apakah terdapat hubungan bermakna atau tidak dari kedua variable, sehingga di dapatkan gambaran makna dari variabel jenis pola asuh orang tua dengan variabel resiko perilaku bullying.

\section{HASIL DAN PEMBAHASAN}

Berdasarkan analisis univariat dan analisis bivariat, didapatkan hasil sebagai berikut :

\section{Analisis Univariat}

\section{Tabel 1}

Distribusi Frekuensi Jenis Pola Asuh Orang Tua Siswa-siswi SMP Pasundan 2 Kota Bandung

\begin{tabular}{lcc}
\hline $\begin{array}{c}\text { Jenis Pola Asuh } \\
\text { Orang Tua }\end{array}$ & F & \% \\
\hline Demokratis & 14 & 20,0 \\
Permisif & 26 & 37,1 \\
Otoriter & 22 & 31,4 \\
Campuran & 8 & 11,4 \\
\hline \multicolumn{1}{c}{ Total } & $\mathbf{7 0}$ & $\mathbf{1 0 0}$ \\
\hline
\end{tabular}

Tabel 1 menunjukkan bahwa dari 70 siswa-siswi SMP Pasundan 2 Kota Bandung, banyak orang tua yang menerapkan jenis pola asuh permisif yaitu 26 orang $(37,1 \%)$.

\section{Tabel 2}

Distribusi Frekuensi Resiko Perilaku Bullying Siswa-siswi SMP Pasundan 2 Kota Bandung

\begin{tabular}{ccc}
\hline $\begin{array}{c}\text { Resiko Perilaku } \\
\text { Bullying }\end{array}$ & F & \% \\
\hline Rendah & 33 & 47,1 \\
Tinggi & 37 & 52,9 \\
\hline Total & $\mathbf{7 0}$ & $\mathbf{1 0 0}$ \\
\hline
\end{tabular}

Tabel 2, menunjukkan bahwa resiko perilaku bullying terbanyak berada dalam katagori tinggi yaitu 37 orang $(52,9 \%)$ 


\section{Analisis Bivariat}

Tabel 3

Hubung Jenis Pola Asuh Orang Tua Terhadap Resiko Perilu Bullying Siswa-siswi SMP Pasundan 2 Kota Bandung

\begin{tabular}{l|c|c|c|c|c|c|l}
\hline \multicolumn{7}{c}{ Resiko Perilaku Bullying } \\
\hline \multicolumn{1}{c}{ Rendah } & Tinggi \\
\hline Pola Asuh & F & $\%$ & F & $\%$ & Total & $\%$ & p-value \\
\hline Demokratis & 11 & 78.57 & 3 & 21,42 & 14 & 100 & \\
Permisif & 11 & 42,30 & 15 & 57,69 & 26 & 100 & \multirow{2}{*}{0,068} \\
Otoriter & 8 & 36,36 & 14 & 63,63 & 22 & 100 & \\
Campuran & 3 & 37,5 & 5 & 62,5 & 8 & 100 & \\
\hline
\end{tabular}

Tabel 3, menunjukkan bahwa jenis pola asuh orang tua yang paling banyak adalah permisif sebanyak 26 orang, dengan tingkat resiko perilaku bullying rendah sebanyak $11(0,42 \%)$, dan resiko perilaku bullying tinggi sebanyak $15 \quad(0,57 \%)$. Analisa data yang digunakan adalah uji korelasi chi-square. Hasil penelitian dibandingkan $p$-value dengan signifikan alpha $(0,05)$, apabila $p$-value lebih kecil dari alpha $(0,05)$, maka terdapat hubungan yang bermakna antara variabel independen dan variabel dependen, akan tetapi, apabila p-value lebih besar dari alpha $(0,05)$, maka tidak ada hubungan antara variabel independen dan variabel dependen.

Jenis pola asuh orang tua siswa-siswi SMP Pasundan 2 Kota Bandung, yang paling mendominasi adalah pola asuh permisif yaitu sebanyak $26 \quad(37,1 \%)$, otoriter sebanyak 22 (22\%), demokratis (14\%) dan campuran sebanyak $8(11,4 \%)$. Resiko perilaku bullying siswa-siswi SMP Pasundan 2 Kota Bandung, yang paling mendominasi adalah tinggi sebanyak 37 orang $(52,9 \%)$. Hasil uji statistik yang peneliti lakukan didapat, nilai $p$-value > 0,05 yaitu 0,068 dengan $r=7,118$, artinya tidak terdapat hubungan yang signifikan antara pola asuh orang tua dengan resiko perilaku bullying, meskipun di dalam tabel 3, didapatkan data yang menunjukkan bahwa siswa-siswi yang dibesarkan dengan pola asuh orang tua permisif dan otoriter cenderung melakukan perilaku bullying, banyak kemungkinan yang dapat menjadi penyebab, mengapa tidak terdapat sebuah hubungan yang bermakna anatr variabel independen dan dependen dalam penelitian ini. 


\section{SIMPULAN DAN SARAN}

Berdasarkan hasil penelitian di SMP Pasundan 2 Kota Bandung, dapat diambil kesimpulan bahwa, hasil uji statistik menunjukan tidak ada hubungan yang signifikan antara variabel jenis pola asuh orang tua terhadap variabel resiko perilaku bullying dengan hasil $p$-value > 0,05 yaitu 0,068 dengan $r=7,118$. Hasil penelitian ini tidak sejalan dengan teori dan tidak sejalan dengan penelitian yang dilakukan oleh Annisa (2012), tentang hubungan pola asuh ibu dengan perilaku bullying remaja dengan jumlah sampel 391 siswasiswi menunjukkan bahwa terdapat hubungan yang bermakna p-value 0,001. Karena menurut hasil penelitian para ibu cenderung menunjukkan kontrol yang lebih tinggi dibandingkan kehangatan atau penerimaan dalam mengasuh anak. Beberapa faktor yang mempengaruhi perilaku bullying menurut Flyn \& Mortono (2009), adalah perbedaan kelas ekonomi, tradisi senioritas, keluarga yang tidak harmonis, pengaruh teman sebaya, media, lingkung sekolah dan pola asuh orang tua. Dengan adanya beberapa faktor yang mempengaruhi perilaku bullying, namun dalam penelitian ini faktor pola asuh tidak terdapat hubungan dengan resiko perilaku bullying bisa dikarenakan ada faktor lain yang lebih mempengaruhi seperti faktor teman sebaya. Menurut peneliti sendiri hal ini disebabkan karena adanya faktor lain diluar orang tua yaitu teman sekolah, karna setiap orang tua pasti memiliki alasan dan tujuan sebelum menetapkan pola asuh yang akan di lakukan pada anaknya dan perilaku anak ketika dirumah dan saat berada di luar atau berasama teman di sekolah cenderung berbeda, itulah sebabnya banyak perilaku buruk yang dilakukan anak-anak salah satunya adalah perilaku bullying.

Saran dari peneliti untuk pihak sekolah diharap memberikan tindakan tegas atau minimal peneguran, larangan, dan berusaha merubah pola pikir siswasiswi untuk menurunkan resiko perilaku bullying siswa-siswi SMP Pasundan 2 Kota Bandung. Untuk siswa-siswi SMP Pasundan 2 Kota Bandung, diharapkan dapat selektif dalam memilih pergaulan agar tidak berdampak buruk bagi diri sendiri, saat ini dan dimasa depan. Untuk perawat dapat melakukan upaya-upaya untuk mencegah atau menanggulangi bullying, perawat dapat memberikan asuhan keperawatan bagi para pelaku atau korban bullying.

\section{DAFTAR PUSTAKA}

Ali, Zaidin. 2010. Pengantar Keperawatan Keluarga. Jakarta : EGC

Azwar, Saifuddin. 2012. Penyusunan Skala Psikologi. Edisi 2. Yoyakarta : Pustaka Pelajar 
Efendi, Ferry \& Mahfudhi. 2009. Keperawatan Kesehatan Komunitas. Jakarta : Salemba Medika

Friedman, M. Marilyn. 2010. Keperawatan Keluarga Teori dan Praktik. Jakarta : EGC

Hidayat, Aziz, Alimul. 2007. Riset Keperawatan dan Teknik Penulisan Ilmiah. Jakarta : Salemba Medika

Hikmat, Mahi M. 2007. Karya Ilmiah dan Metode Penelitian. Bandung : LPPM Universitas Al-Ghifari

Indria, Karina, Nindyawati, dan Ayu, Dwi. 2007. Kajian Konformitas dan Kreatifitas Affective Remaja. Jurnal Provita. Vol. 3, No. 1. Fakultas Psikologi Untar Jakarta dan Yayasan Obor

Kismartani, Dian, Ade. 2010. Studi Deskriptif, Identifikasi Masyarakat Mengenai Faktor-faktor yang Mempengaruhi Bullying. Skripsi. S1 Fakultas Psikologi UNIKA.

Marliyah, lina, Fransischa IR, Tommy, Suyasa. 2007. Persepsi Terhadap Dukungan Orang Tua Dan Pembuatan Keputusan Karir Remaja. Jurnal Provitae vol.

Nursalam. 2008. Konsep dan Penerapan Metodelogi Penelitian Ilmu Keperawatan serta Pedoman Skripsi,
Tesis, dan Instrumen Penelitian Ilmu Keperawatan. Edisi 2. Jakarta : Salemba Medika

Soekidjo, Notoatmodjo. 2007. Kesehatan Masyarakat Ilmu dan Seni. Edisi Revisi. Jakarta: Rineka Cipta

Soetjiningsih. 2007. Tumbuh Kembang Remaja Dan Permasalahannya. Jakarta : Sagung Seto

Suyanto, dan Narwoko. 2007. Sosiologi Teks Pengantar dan Terapan. Jakarta : Kencana Media Group

Sugiyono. 2008. Metode Penelitian Kunatitatif Kualitatif dan $R \& D$. Bandung : Alfabeta.

Widyarini, Nilam. 2009. Relasi Orang Tua \& Anak. Jakarta : Elex Media Komputindo

Wiggins, J.A, dan Zanden, J.V. 1994. Social Psychology, fifth edition. New York : Mc. Graw-Hill

Wong, dkk. 2002. Buku Ajar Keperawatan Pediatrik Wong. Edisi 6. Volume 1. Jakarta : EGC

Yayasan Semai Jiwa Amini (Sejiwa). 2008. Bullying Mengatasi Kekerasan di Sekolah dan Lingkungan Sekitar Anak. Jakarta : Grasindo 